JOSIP BEBER

Sveučilište u Zagrebu Geotehnički fakultet

Primljeno: 24. 09. 2018.

ROBERT PAŠIČKO

Prihvaćeno: 18. 10. 2018.

Sveučilište u Zagrebu Geotehnički fakultet

STJEPAN CAR

Zelena energetska zadruga

rpasicko@gfv.hr; bj2267@gfv.hr

DOI: https://dx.doi.org/10.21857/yvjrdcqxvy

\title{
NOVI KONCEPTI ZELENOG RAZVOJA I NJIHOVA PRIMJENA U ENERGETICI
}

Razvoj energetike uz sebe veže inovaciju i konstantnu prilagodbu kroz distribuciju, potrošnju i proizvodnju energije. U ovom radu bit će opisani novi koncepti zelenog razvoja $i$ njihova primjena u energetici s fokusom na električnu energiju. Sve više cijene fosilnih energenata (nafte, plina), nuklearne katastrofe te sve veće posljedice po okoliš (klimatske promjene, onečišćenje tla, zraka, vode i sl., smanjenje bio raznolikosti) ubrzale su potrebu za tranzicijom trenutnog energetskog sustava prema održivijem modelu razvoja. Korištenje obnovljivih tehnologija omogućava bolju kvalitetu okoliša, iskorištavanje lokalnih resursa i poticanje lokalne ekonomije te su većinom zamišljeni kao proi elektroenergetski sustavi koji su koristili energiju lokalno te su bili manjih kapaciteta. Nakon ekonomske krize 2008. godine sve su značajniji novi modeli razvoja koji se opisuju terminima kao što su zeleni razvoj (eng. green growth), niskougljični razvoj (eng. low carbon development), zelena ekonomija (eng. green economy) i slični. Dodatnim razvojem tehnologije (četvrta industrijska revolucija, Internet stvari, bolja umreženost) javljaju se novi načini poslovanja koji uključuju korisnike u proces odlučivanja, investiranja te upravljanja postojećim $i$ novih energetskim sustavima te energetskim tortkama.

Kako bi energetske tvrtke ostale u korak s vremenom te se prilagodile tržištu, energetskim politikama, novim ekološkim normama, potencijalnim investitorima moraju modernizirati svoje poslovanje. Osim korištenja obnovljivih izvora energije moderne energetske tortke karakterizira fleksibilnost u pogledu prihvaćanja inovativnosti, korištenja novih financijskih koncepata, implementacije novih tehnologija, povećanja transparentnosti u poslovanju te razvoju usluga pogodnih za krajnje korisnike. Ovaj rad će poslužiti kao pregled novih koncepata zelenog razvoja u energetici. 


\section{UVOD}

\section{Zeleni razvoj}

Zadnjih 250 godina intenzivnog gospodarskog razvoja i rasta nije se uzimala u obzir šteta učinjena okolišu. Kako bi se osigurao dugoročni rast te preokrenuo trend degradacije okoliša potrebno je suočavanje s rastućim okolišnim izazovima te potaknuti zeleni razvoj uz očuvanje prirodnih resursa. Osim pitanja zaštite okoliša zeleni razvoj uključuje područja ekonomije, politike, društvenih promjena, energetike, razvoja tehnologije, industrije itd. (Worldbank, 2012). Nakon ekonomske krize 2008. dolazi do drugačijeg pogleda na klimatske promjene, ekonomiju i gospodarstvo. Iako klimatske promjene predstavljaju prijetnju trenutačnom načinu života postoji ideja razvoja i ekonomskog rasta kroz prilagodbu i umanjivanje učinka klimatskih promjena kroz isprepletanje niskougljičnog razvoja, zelene ekonomije i zelenog razvoja (Pašičko, 2014).

Niskougljični razvoj stavlja fokus na smanjenje emisija stakleničkih plinova te osigurava osnove za investiranje i olakšavanje donošenja političkih odluka na nacionalnoj razini prema zelenom razvoju. Niskougljičani razvoj razlikuje se od pojma zelene ekonomije i zelenog razvoja po dugoročnom pristupu i isticanju važnosti smanjenja emisija stakleničkih plinova. Termin zelene ekonomije sličan je s definicijom održivog razvoja te uključuje niskougljični razvoj s naglaskom na socijalnu jednakost kroz smanjenje ekoloških i okolišnih rizika. Zeleni razvoj je gospodarski razvoj koji potiče zelenu ekonomiju uz očuvanje okoliša, klimatsku stabilnost, efikasnost u korištenju prirodnih resursa te razdvajanje ekonomskog rasta od iscrpljivanja prirodnih resursa. Preokret u shvaćanju ekonomije, politike i gospodarstva prema niskougljičnom razvoju, zelenoj ekonomiji i zelenom razvoju imaju dodirne točke kao što su: implementacija održivog razvoja uz indikatore primjene, mobilizacija financijskih resursa i partnerstva, razvoj zelenih poslova, korištenje zelenih tehnologija, održiva potrošnja (promjene $u$ ponašanju), porast cijene onečišćenja kroz različite mehanizme, stvaranje i dugoročno planiranje kroz nacionalne politike (Pašičko, 2014).

Prema Strateškim odrednicama za razvoj zelenog gospodarstva Republike Hrvatske koncept „zelenog gospodarstva“ podrazumijeva tehnološki razvoj, novu industrijalizaciju, restrukturiranje poslovnog sektora i infrastrukture prema prirodnim, ljudskim i kapitalnim kapacitetima i potrebama, uz istovremeno učinkovito korištenje energije, smanjenje emisija stakleničkih plinova, učinkovito korištenje prirodnih resursa, stvaranjem manje otpada i smanjenjem socijalnih nejednakosti (Ministarstvo zaštite okoliša, prostornog uređenja i graditeljstva, 2011). 
Primjerice eksploatacija, prerada nafte i naftni derivati negativno utječu na sve sastavnice okoliša, a sama cijena nafte diktira političku, gospodarsku i ekonomsku stabilnost (slika 1). Europska Unija još uvijek uvelike ovisi o uvezenoj nafti s 89\% koja većinom dolazi iz Rusije prema podacima Eurostata (2015.). Hrvatska se nalazi ispod EU prosjeka po uvozu s $80 \%$ uvoza čime je isto tako ranjiva po pitanju fluktuacija cijena nafte (Eurostat, 2015).

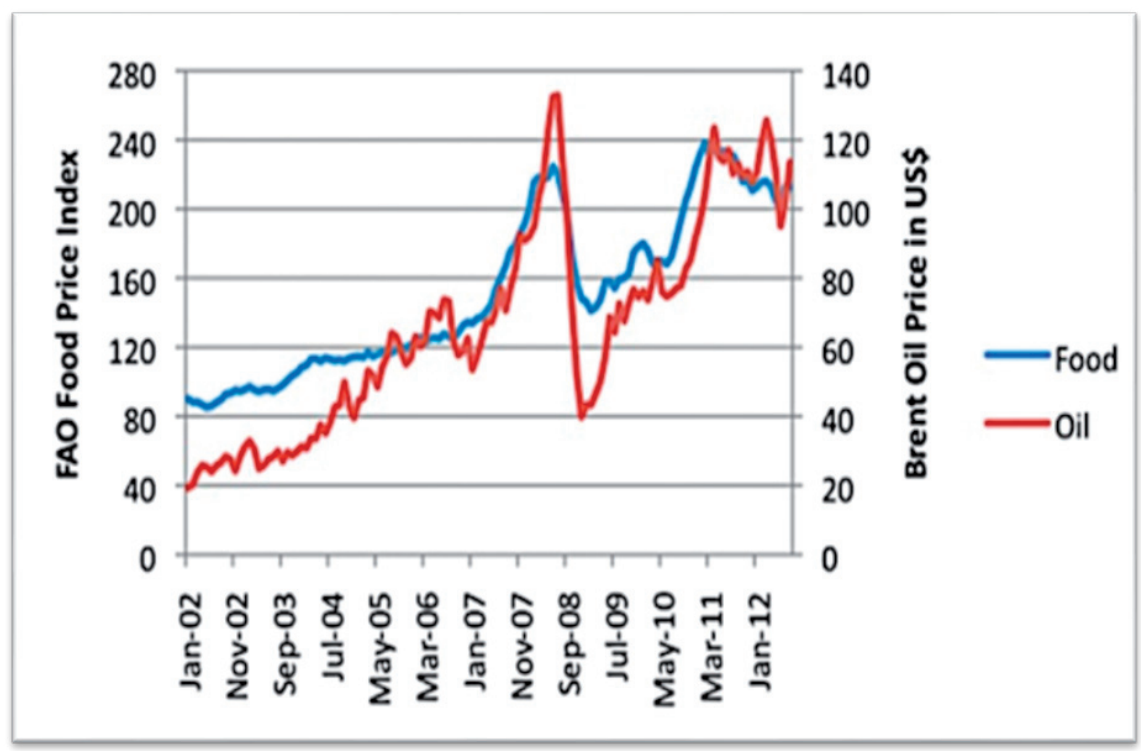

Slika 1. Povezanost cijene hrane i nafte s naglaskom na dodatne šokove nakon ekonomske krize (Tverberg, 2013)

Sagorijevanjem fosilnih goriva (nafte i plina) rastu koncentracije stakleničkih plinova koji ubrzavaju klimatske promjene. Promjena klime utječe na brže zagrijavanje zaleđenih dijelova svijeta, povišenje temperatura oceana, javljanje klimatskih anomalija, ugrožavanje ljudskih djelatnosti (agrikultura, transport, energetika), nestanak vrsta i staništa (Environmental Defense Fund, 2018).

Posljedice klimatskih promjena izazvale su pomak u političkoj volji EU-28 i ostalih zemalja potpisnica klimatskog sporazuma u Kyotu i Pariškog sporazuma s namjerom smanjenja stakleničkih plinova, prilagođavanja posljedicama klimatskih promjena te smanjenju njihovih utjecaja. Kako bi se uključio veći broj zemalja u borbi protiv klimatskih promjena te povećala odgovornost između zemalja potpisnica 12. 12. 2015. potpisan je Pariški sporazum. Glavni cilj Pariškog sporazuma ograničava globalno zatopljenje na razinu manju od $2{ }^{\circ} \mathrm{C}$, a obuhvaća 
razdoblje od 2020. nadalje. Glavna poglavlja Pariškog sporazuma su: solidarnost (potpora zemljama u razvoju pri borbi protiv klimatskih promjena), ambicija (donošenje petogodišnjih izvješća o doprinosima pojedinih zemalja u borbi protiv klimatskih promjena), doprinosi (donošenje nacionalnog plana za smanjivanje emisija) i transparentnost (zemlje potpisnice će izvještavati stanje o napretku međusobno i javnosti). Potpisivanjem sporazuma želi se istaknuti važnost i ozbiljnost pitanja klimatskih promjena pri čemu se uključuju različiti akteri u sam proces rješavanja izazova koji su pred nama (European Commision, 2018).

Jedan do važnih aktera je sektor energetike koji emitira 66\% stakleničkih plinova ako se uključi transport i energija potrošena u zgradama (IPPC, 2007). Energetski miks nije se izmijenio značajno u 25 godina (udio fosilnih goriva je $82 \%$ ), a procjenjuje se da će se smanjiti na samo 75\% do 2035. s korištenjem obnovljivih izvora energije. Kako bi se dodatno smanjio udio potrebne su radikalne promjene u energetskom sektoru po pitanju emisija stakleničkih plinova (IEA, 2014).

\section{Konvencionalna proizvodnja električne energije}

Konvencionalna proizvodnja energije odnosi se na masovnu proizvodnju $u$ centraliziranim postrojenjima. Mjesto proizvodnje energije često je veoma udaljeno od krajnjeg korisnika kroz visoko naponsku mrežu, a energetska mreža je distribuirana kako bi opskrbila velik broj korisnika. Centralizirana proizvodnja može prouzročiti regionalne i lokalne posljedice po okoliš (EPA,2018).

Negativne posljedice po okoliš proizvodnja iz konvencionalnih goriva (EPA,2018):

- onečišćenje zraka ugljičnim dioksidom, sumpornim dioksidom, dušikovim oksidima, živom i česticama nastalih pri sagorijevanju goriva kao što su nafta, ugljen i različita biogoriva;

- otpadna voda (vraćanje vode više temperature u okoliš i isparavanje);

- otpad (kreiranje otpadnog pepela i nuklearnog otpada);

- trajno oštećenje zemlje (centralizirana postrojenja zauzimaju velike površine zemljišta kao i ostali mrežni elementi za prijenos električne energije).

Potreba za izmjenom centraliziranih energetskih sustava proizlazi iz investicijskih rizika velikih energetskih postrojenja, nesigurnosti oko transporta energenata, utjecaja na klimatske promijene, varijacije u cijeni fosilnih goriva i negativnih posljedica po okoliš (Bouffard \& Kirschen, 2008). Prijenos energije na velike udaljenosti također uzrokuje gubitke te je upitno koliko dugo će takva postrojenja biti isplativa $\mathrm{u}$ odnosu na lokalna postrojenja za proizvodnju energije (EPA,2018). 


\section{Energetska tranzicija i decentralizirana proizvodnja električne energije}

Ponukana prvim naftnim krizama sedamdesetih godina prošlog stoljeća; Europa je pionir u prelasku s konvencionalnih izvora energije na obnovljive izvore s četiri desetljeća iskustva u energetskoj tranziciji koja uključuje implementaciju energetske efikasnosti, upravljanje energetskom bilancom te socijalne, kulturne, okolišne, ekonomske i tehnološke aspekte. Prema izvješću RET21 iz 2016. energetska tranzicija odvija se u pozitivnom smjeru, a pokazatelji su sljedeći: pad cijene troškova solarnih elektrana i vjetroelektrana, povećanje kapaciteta OIE te razdvajanje ekonomskog rasta i emisija $\mathrm{CO}_{2}$. Pokazatelji su popraćeni s razvojem poslovnih modela kako bi se implementirale obnovljive tehnologije za proizvodnju energije, što pospješuje promjenu paradigme s fosilnih goriva na obnovljive izvore energije (REN21, 2017).

Velike energetske tvrtke pokazuju popriličan otpor energetskoj tranziciji ulažući u centralizirana postrojenja za proizvodnju energije iz konvencionalnih goriva te lobiranjem za ista. Velike energetske tvrtke proizvode polovicu energije EU te bilježe konstantan pad u broju dioničara, dok manje tvrtke koje investiraju u OIE bilježe porast korisnika i kapitala. Velike energetske tvrtke prilagođavaju se sporo potrebama tržišta, razvoju OIE, političko-društvenim promjenama, poboljšanim normama po pitanju sprečavanja onečišćenja i smanjenju emisija $\mathrm{CO}_{2}$. Držeći se dosadašnjeg poslovanja velike energetske tvrtke imaju sve više izazova kako bi bile konkurencija malim dionicima na energetskom tržištu koji decentralizirano proizvode energiju po niskim cijenama prilikom čega velike energetske tvrtke gube dio tržišta te su prisiljene prodavati energiju po nižim cijenama (uz više troškove proizvodnje energije iz zastarjelih postrojenja). Porast cijene održavanja i modernizacije postrojenja koja koriste ugljen i plin udaljavaju velike energetske tvrtke od energetskih tržišta, državnih politika (tablica 1), potencijalnih investicija (slika 2), korisnika i pozitivnog javnog mišljenja (Greenpeace, 2014.).

Tablica 1. Udjeli proizvodnje energije iz OIE veliki proizvođači i EU-27 (Greenpeace, 2014.)

\begin{tabular}{|c|c|c|}
\hline Obnovljivi izvori energije & Velikih 10 energetskih tvrki & EU-27 \\
\hline OIE (bez hidroenergije) & $4 \%$ & $13 \%$ \\
\hline OIE (vjetaroelektrane) & $2,7 \%$ & $6,4 \%$ \\
\hline OIE (hidroenergija) & $8 \%$ & $11,7 \%$ \\
\hline
\end{tabular}

U 2017. godini je uloženo 265 milijardi USD u izgradnju postrojenja za proizvodnju obnovljive energije (bez hidroelektrana s 45 milijardi dolara ulaganja). Na globalnoj razini ulaganje u obnovljive izvore energije je poraslo na $68,2 \% \mathrm{u}$ odnosu na ukupna ulaganja u energetska postrojenja. Što otvara tržište koje velike energetske tvrtke nisu u potpunosti prepoznale kao relevantno (REN21, 2017). 


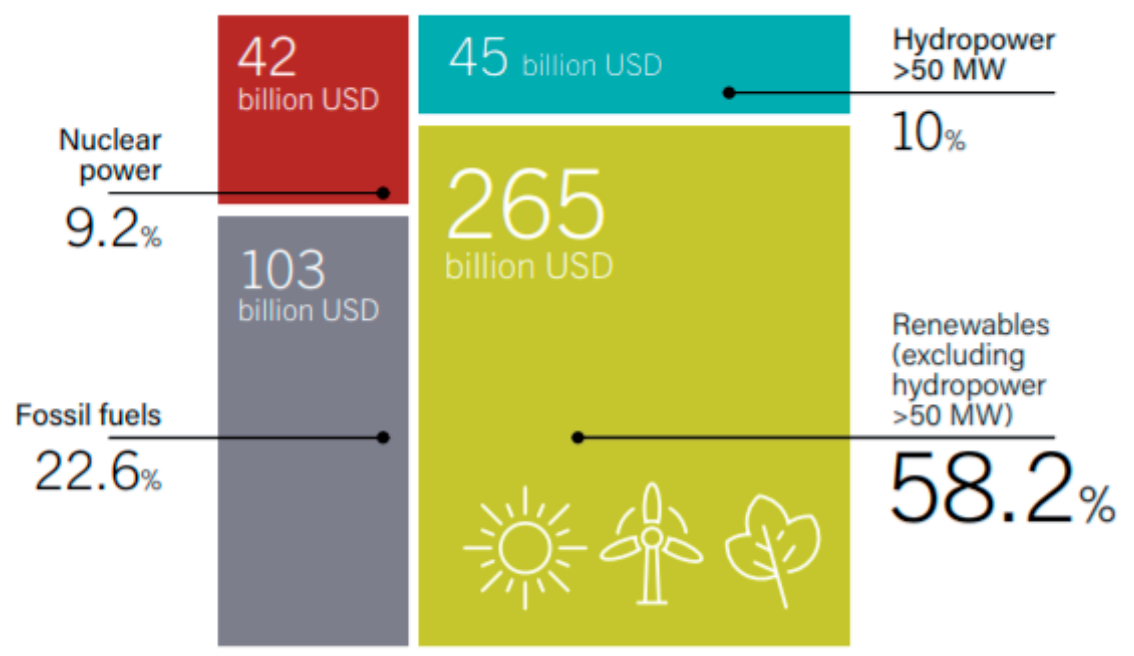

Slika 2. Ulaganje u pojedine energente na globalnoj razini u 2017. god. (REN21, 2017)

S porastom udjela obnovljivih izvora energije dolazi do decentralizacije energetskih sustava. Obnovljivi izvori energije mijenjaju energetsku sliku Europe proizvodnjom energije iz manjih postrojenja lokalnog karaktera koja se nalaze u blizini krajnjih korisnika čime se smanjuju energetski gubitci prilikom prijenosa kroz mrežu (Bouffard \& Kirschen, 2008). Nestanak energije u današnjoj mreži uglavnom ima domino efekt za ostale djelatnosti kao što su komunikacije, promet, sigurnost i bankarstvo. Modernizirani energetski sustavi nude veću sigurnost pri takvim događajima zbog digitalnih tehnologija koje služe za komunikaciju u oba smjera (Smartgrid, 2018). Komunikacija omogućava mobilizaciju potrebnih resursa uz najveću efikasnost npr. slanje materijala za popravak, zatim detektiranje manjih kvarova koji bi mogli prouzročiti veće kvarove, slanje energije tamo gdje je najpotrebnije za vrijeme kvara, korištenje energije nezavisnih proizvođača za pokrivanje energetskih potreba za vrijeme kvarova).

Decentralizirani sustavi odvojeni su od glavnog transporta energije te mogu koristiti druge izvore za proizvodnju energije kao što je prirodni plin što im omogućuje samostalnost i otpornost na kvarove kakve susrećemo u konvencionalnim mrežama i postrojenjima za proizvodnju električne energije (Bouffard \& Kirschen, 2008). Ugradnjom manjih proizvodnih jedinica potiče se razvoj energetskih tvrtki i rastu faktori važni za predviđanje energetske bilance. Kako bi se iskoristio potencijal decentralizirane energije potrebno je: kreirati informacijski 
sustav dostupan građanima i upraviteljima mreže, poticati promjene u poslovnim modelima koji omogućuju lakšu dostupnost kapitala, poticati inovacije $\mathrm{u}$ materijalima i metodama koji se koriste u solarnim postrojenjima i vjetroelektranama, poticati inovacije u upravljanju kompleksnim stohastičkim modelima opskrbe energijom te kreirati sustav koji će biti u interakciji s potražnjom i pohranom energije. Decentralizacija omogućuje smanjenje utjecaja i autoriteta velikih energetskih tvrtki te ga seli na građane ili manje kompanije (World Economic Forum, 2018).

\section{NOVI KONCEPTI ZELENOG RAZVOJA U ENERGETICI}

Liberalizacija i deregulacija tržišta te poticanje obnovljivih izvora energije i novih zahtjeva za postizanje energetske učinkovitosti postavljaju sve veći izazov $\mathrm{u}$ energetskom planiranju i instaliranju novih kapaciteta. U ovom poglavlju navedeni su neki od novih modela zelenog razvoja energetike - koji uključuju i inovativne financijske modele, veću korist za lokalnu zajednicu i lokalnu ekonomiju; te demokratizaciju vlasništva i donošenja odluka u sektoru energetike.

\section{Grupno financiranje projekata zelene energije (eng. crowdfunding)}

Jedan od inovativnih modela financiranja obnovljive energije koji se značajno pojavio na zapadnoeuropskim tržištima nakon 2008. godine jest grupno financiranje koje omogućuje ulaganje građana u projekte, ideje, proizvode ili usluge od njihova interesa (Hafner et al., 2017). Financiranjem različitih projekata zelene energije postoji mogućnost za uključivanje građana, energetskih zadruga, udruga, lokalnog stanovništva, javnih ustanova te privatnih tvrtki u zajedničku suradnju. 2015. provedeno je istraživanje na temu grupnog financiranja obnovljivih izvora energije putem Internet ankete koja je bila usmjerena na 29 Europskih zemalja. Rezultati ankete pokazali su interes građana za investiranje u obnovljive izvore energije (45,2\% ispitanika je investiralo), a osim toga polovica građana (50,3\%) koji investiraju putem grupnog financiranja već su uložili svoj novac u obnovljive izvore energije. Najpopularniji modeli investiranja u obnovljive izvore prema građanima je grupno financiranje temeljeno na udjelima i grupno financiranje temeljeno na zajmu (Bergman et al., 2016). Postoje različiti modeli grupnog financiranja (tablica 2) pomoću kojih je definiran odnos prema investitorima. 
Josip Beber, Robert Pašičko, Stjepan Car: Novi koncepti zelenog razvoja i njihova primjena u energetici Radovi Zavoda za znanstveni rad HAZU Varaždin; br. 29, 2018., str. 325-348

Tablica 2. Modeli grupnog financiranja (Hafner et al. , 2017)

\begin{tabular}{|c|c|}
\hline Model zajma & $\begin{array}{c}\text { Investitori pozajmljuju novac projektu s namjerom } \\
\text { ostvarivanja dobiti }\end{array}$ \\
\hline Model udjela & $\begin{array}{c}\text { Investitori ulaganjem postaju vlasnici dijela projekta u koji } \\
\text { ulažu }\end{array}$ \\
\hline Model nagrade & $\begin{array}{c}\text { Investitor ulaganjem očekuje nagradu (npr. proizvod od } \\
\text { projekta) }\end{array}$ \\
\hline Donacijski model & $\begin{array}{c}\text { Ulaganjem investitor ne očekuje dobit nego zadovoljstvo } \\
\text { sudja u projektu }\end{array}$ \\
\hline Hibridni model & Kombinacija različitih modela grupnog financiranja \\
\hline
\end{tabular}

Platforme za skupno financiranje su mrežna mjesta koja omogućavaju dolaska u dodir onih kojima treba novac i ulagača. Budući da platforme često funkcioniraju po načelu "sve ili ništa", što je povoljno po ulagača: ako se preko platforme skupi dovoljno novca, onaj koji želi prikupiti novac isti i dobiva, a ako se ne sakupi dovoljno novca, ulagači dobe svoj novac natrag. Time prikupljanje sredstava reklamira projekt, a mnoštvo malih investitora disperzira mogući rizik ako projekt ne uspije. Grupno financiranje (eng. crowdfunidng) je alternativan način investiranja i financiranja projekata. Proces investiranja i pribavljanja sredstava odvija se putem Interneta s ciljem uključivanja ljudi na temelju njihovih interesa kako bi malim uplatama došli do dovoljnog iznosa za realizaciju projekata. Novac se obično prikuplja u roku od 30 do 60 dana, a cijeli proces prikupljanja je transparentan jer je svaka uplata vidljiva. Grupno financiranje omogućava pristup kapitalu bez kolaterala, a ideja prođe proces validacije prije nego što proizvod dođe na tržište zbog Internet kampanje. Prikupljanje sredstava reklamira projekt, a mnoštvo malih investitora disperzira mogući rizik ukoliko projekt ne uspije (Hafner et al. , 2017).

Citizenergy projekt pokrenut je 2014. godine uz potporu programa Intelligent Energy Europe u svrhu stvaranja portala koji će spojiti građane zainteresirane za ulaganje u projekte OIE (obnovljivi izvori energije) i EE (energetska efikasnost) s investitorima koji traže sredstva za svoje inicijative diljem Europe. Citizenergy uspješno funkcionira već četiri godine što potvrđuje da je od osnutka pa do danas sakupljeno preko 39 milijuna EUR i uspješno pomoglo financirati 54 projekta što je jednako oko $115 \mathrm{MW}$ instalirane zelene energije u državama člani- 
cama Europske Unije (Citizenenergy, 2018). Glavni cilj ovog projekta je smanjenje barijere između investitora i poduzetnika te potaknuti prekogranično financiranje preko platforma unutar EU. Da bi proces bio više transparentan članice EU trebaju uskladiti zakonodavstvo o skupnom financiranju kako bi ulagačima olakšali i pojednostavili investiranje u OIE projekte i time otvorili jedinstveno tržište na razini cijele Europe.

Bettervest je prva svjetska Internet platforma za financiranje energetski efikasnih projekata, koji uključuje obične građane kroz investiranje u projekte koji su klimatske tematike, a odnose se i na ekonomiju i društvo. Poslovni model temelji se na prikupljanju malih iznosa koji iznose 50 EUR od individualnih investitora kod kojih investitori uživaju povrat od energetskih ušteda ili proizvodnje energije. Projekte mogu pokrenuti lokalne vlasti, nevladine organizacije ili poduzeća, a Internet platforma za skupno financiranje omogućuje građanima ulaganje $u$ energetsku efikasnost kroz koju se smanjuju troškovi, potrošnja energije i emisije ugljičnog dioksida. Vlasnici projekta isplaćuju dogovorenu fiksnu godišnju dobit investitorima koja je definirana ugovorom. Dobit investitorima dijeli se na: dogovorenu kamatu i dio početne investicije. Nakon ugovorenog razdoblja ugovor se ukida i mjere energetske efikasnosti ostaju u rukama vlasnika projekta. Internet platforma uzima naknadu za proviziju, a cijena naknade ovisi o ukupnoj cijeni investicije i godišnjoj naknadi rukovođenja (Bettervest, 2018).

Istraživanje tvrtke CE Delft pokazalo je kako bi polovica građana EU moglo proizvoditi svoju energiju do sredine ovog stoljeća. Tehnološka rješenja su dostupna, a poslovni modeli poznati te se u zemljama poput Njemačke i Danske koriste već godinama. U Republici Hrvatskoj grupnim financiranjem po modelu mikro zajma izgrađena je solarna elektrana u gradu Križevci. Zelena energetska zadruga pokrenula je inicijativu ulagačkog modela u projekte zelene energije putem grupnog financiranja (u ovom radu fotonaponska elektrana snage $30 \mathrm{~kW}$ ). Kako bi Hrvatska iskoristila svoje energetske resurse (sunce, biomasu vjetar) potrebni su novi alati za dizanje kapitala za takve projekte. Poslovni model temeljen je na mikro zajmovima tj. na grupnom financiranju temeljenom na zajmu. Zelena energetska zadruga ima ulogu posrednika između investitora (građana) i korisnika elektrane (Razvojni centar i tehnološki park Križevci). Investitori potpisuju ugovor na 10 godina prilikom kojih godišnje primaju naknadu od 4,5\% od zadruge. Zelena energetska zadruga je sredstvima od zajmova kupila fotonaponsku elektranu i postavila ju na krov Razvojnog centra i tehnološkog parka Križevci. Prilikom ostvarenih ušteda u trajanju od 10 godina Zelena energetska zadruga dobivati će naknadu koja je fiksna i jednaka uštedama koje su postignute radom fotonaponske elektrane. Nakon 10 godina fotonaponska elektrana prelazi u vlasništvo Razvojnog centra i tehnološkog parka Križevci. Životni vijek 
elektrane je značajno duži od 10 godina te je procijenjen rad s efikasnošću od $80 \%$ do 25 godina starosti elektrane. Razvojni centar i tehnološki park Križevci će prvenstveno pokrivati vlastite potrebe za energijom, a viškovi će se predavati u mrežu prema dogovoru s opskrbljivačem, po modelu samoopskrbe "kupac s vlastitom proizvodnjom".

Neke od prednosti korištenja navedenog modela financiranja za korisnika (Križevački poduzetnički centar i tehnološki park) su: transfer rizika s klijenta na Zadrugu, niži troškovi za energiju, optimizacija i održavanje elektrane te zaštita okoliša (smanjivanje emisija ugljikovog dioksida kroz korištenje obnovljivih izvora energije).

Putem kampanje skupljena su sva sredstva za elektranu u iznosu od 230.000 kn u roku od 10 dana, a sudjelovalo je 53 ulagača. Tokom prikupljanja sredstava iskazan je interes za daljnja ulaganja od strane 104 fizičke osobe s iznosom od gotovo 450.000 kn (Zelena energetska zadruga, 2018). Dizanje kapitala je važno za razvoj bilo kojeg sektora djelatnosti tako i energetskog sektora. Kroz primjere grupnog financiranja je prikazan alternativan model financiranja OIE te mogućnosti za razvoj energetskog sektora kroz pružanje mogućnosti investiranja u pojedine lokalne projekte kojima se uklanja NIMBY efekt sudjelovanjem građana.

\section{Građanska energija-ulaganje u solarne elektrane putem najma}

Bečka elektroprivreda (Wien Energie) potaknula je razvoj poslovnog modela izgradnje sunčanih elektrana financiranog najmom građana. Ulaganjem u građanske sunčane elektrane postiže se više pogodnosti za same građane - ekološka osviještenost i zaštita okoliša, povrat ulaganja, poboljšanje kvalitete života u vlastitome gradu, dodavanje vrijednosti lokalnoj zajednici te manja ovisnost o uvozu energije. (Smart City Wien, 2018).

Koncept funkcionira na sljedeći način: elektroprivreda (velika energetska tvrtka) je zadužena za gradnju i upravljanje sunčanom elektranom, te također za tehničke i ekonomske rizike. Panele kao i sve ostale dijelove elektrane, od njih može otkupiti svaka fizička osoba s prebivalištem u zemlji. Građani mogu kupiti panel po određenoj cijeni, konkretno $950 €$ po komadu, čime postaju vlasnici panela i nakon toga elektroprivreda iznajmljuje panel od njih, individualnih građana, koji za to primaju godišnju naknadu u skladu sa sklopljenim ugovorom. Na kraju ugovornog razdoblja, koje obično iznosi 20 godina kao minimalni predviđeni vijek trajanja modula, čitavo se ulaganje s uključenim dogovorenim kamatama vraća građaninu koji je uložio. Vlasnici panela u svakome trenutku trajanja ugovora imaju mogućnost vratiti panele u svome vlasništvu nazad elektroprivredi po punoj cijeni (Wien Energie, 2018). Od 2012. godine gotovo 6.000 
ljudi se uključilo u različite projekte te su do sada investirali preko 20 milijuna EUR. Do sada je izgrađeno 26 sunčanih elektrana, kao i četiri vjetroelektrane. Prema procjenama, do 2030. godine bi se iz obnovljivih izvora moglo proizvoditi $40 \%$ ukupne električne energije u gradu. Ovo je prvi put da se participativni model ovoga tipa uspješno implementirao na urbanom području, te se pokazao ekonomski isplativim i bez poticaja (Smart City Wien, 2018).

\section{Model investiranja u sunčane elektrane uz sustav neto-mjerenja putem pružanja energetskih usluga}

Uslijed snažnog pada cijena sunčanih sustava i baterija za skladištenje električne energije proteklih godina te očekivanog nastavka ovog trenda, javljaju se prilike za razvoj poslovnih modela koji uključuju instalacije sunčanih sustava sa ili bez baterija za skladištenje električne energije i po tržišnim uvjetima.

Temeljem svega navedenog, dolazi do snažnog rasta instalacija sunčanih elektrana na mjestu potrošnje električne energije u EU. Također, procjenjuje se da bi ovo tržište u Republici Hrvatskoj moglo već u razdoblju od 2018. do 2020. godine vrijediti oko 150 mil. EUR te dodatnih od oko 500 do preko $1 \mathrm{mlrd}$. EUR u razdoblju od 2021. do 2030. godine (Ministarstvo zaštite okoliša i energetike, 2017).

Ovakav model funkcionira u Sloveniji gdje je na snazi Uredba o samoopskrbi električnom energijom iz OIE. U skladu s njome, sunčane elektrane za samoopskrbu djeluju po sustavu neto mjerenja, što u praksi znači da korisnik u svom domaćinstvu postavlja elektranu koja zadovoljava njegove potrebe. Sustav neto mjerenja omogućava pohranjivanje viška dobivene električne energije u sustav i korištenje električne energije iz sustava kada sunčana elektrana ne proizvede dovoljno energije za vlastite potrebe. Mrežni sustav djeluje kao mjesto pohrane energije, pri čemu pouzdanost opskrbe energijom ostaje nepromijenjena. Prilikom obračuna električne energije i mrežarine uzima se u obzir samo ona količina električne energije $(\mathrm{kWh})$ koja predstavlja razliku između preuzete i dodijeljene radne električne energije $(\mathrm{kWh})$, očitane na istom mjernom mjestu jednom godišnje (Republika Slovenija, 2015). S ovakvim regulatornim okvirom nema potreba za instalacijom baterija na mjestu potrošnje te stoga poslovni model ne predviđa ugradnje baterija za kućanstva.

Kao primjer ovog poslovnog modela, slovenska firma GEN-i Sonce nudi prihvatljive financijske modele, izgradnju elektrana, otkup energije te prodaju energije. Također su preuzeli ulogu dobavljača energije i poslovnog partnera različitih tvrtki koje zajedno sudjeluju u energetskoj tranziciji (Gen-isonce, 2018). GEN-I je razvio inovativni model financiranja koji omogućava investitoru otpla- 
ćivanje u skladu s vlastitim mogućnostima. Temelji se na uštedi od oko $75 \%$ na računu električne energije kojom se može financirati investicija u elektranu, bez ulaganja svojih sredstava tj. treba imati samo pogodan krov za postavljanje. Ova ušteda se troši za povrat investicije. Nakon povrata investicije sunčani sustav je $u$ vlasništvu korisnika (poduzeća, obiteljskih kuća, zgrada itd.).

\section{Model ulaganja u energetsku tranziciju od strane gradova}

Sporazum gradonačelnika (eng. Covenant of Mayors) jedna je od najvažnijih inicijativa Europske unije usmjerena na aktivno uključenje lokalne i regionalne uprave u borbu protiv klimatskih promjena, a ujedno prva i najambicioznija inicijativa Europske komisije usmjerena na kontinuirano sudjelovanje gradskih uprava i samih građana $\mathrm{u}$ borbi protiv globalnog zatopljenja. Potpisivanjem Povelje gradonačelnici se obvezuju na provedbu programa 20-20-20 i primjenu konkretnih mjera energetske učinkovitosti razvijenih u Akcijskim planovima energetski održivog razvitka (eng. Sustainable Energy Action Plan, SEAP) kako bi do 2020. smanjili emisije CO2 na svojem području za najmanje $20 \%$ te pridonijeli ispunjavanju osnovnih ciljeva Europske energetske politike. Do sada je Sporazumom gradonačelnika obuhvaćeno 6.913 europskih jedinica lokalne i regionalne samouprave, od toga 78 gradova u Hrvatskoj. U gradovima i općinama često postoji politička volja da se realiziraju konkretne mjere razvijene Akcijskom planovima, ali im nedostaju stručna znanja i/ili financijska sredstva za implementaciju projekata i inicijativa. Iz tog razloga lokalne vlasti mogu ulaziti u strateška partnerstva s energetskim kompanijama i građanskim inicijativama kao što su energetske zadruge (Convenant of Mayors, 2018).

U ovom modelu lokalna vlast ili privatni partner dodatno mogu uključiti lokalno stanovništvo u strukturu vlasništva ili proces odlučivanja. Tijekom 2017. godine gradovi diljem Europske unije proveli su niz konkretnih inicijativa za razvoj i primjenu novih i inovativnih tehnologija radi potpore energetskoj tranziciji (Convenant of Mayors, 2018) .

Sa sve većom liberalizacijom energetskog tržišta i lokalne vlasti se uključuju u ovu djelatnost. Više britanskih gradova osnovalo je vlastite tvrtke za opskrbu električnom energijom, s dva temeljna motiva: i) socijalnim (smanjenje energetskog siromaštva) i ii) okolišnim (povećanje udjela obnovljivih izvora energije u ukupnoj potrošnji energije). Prva energetska tvrtka u vlasništvu grada u Ujedinjenom Kraljevstvu bio je „Robin Hood Energy“, osnovan 2015. godine na inicijativu grada Nottingham, a dominantno orijentiran prema kućanstvima. Slične inicijative pokreću se u Škotskoj, Bristolu i Londonu. 
Prvenstveno, činjenica da je osnivač i vlasnik tvrtke jedinica lokalne samouprave ukazuje da je vitalno zainteresirana za očuvanje lokalnih radnih mjesta i doprinos lokalnom gospodarstvu, iako poslovni model tvrtke dotiče svo stanovništvo Ujedinjenog Kraljevstva. Sav eventualni višak sredstava koje tvrtka uprihodi, vraća se u lokalnu zajednicu, Grad s tim sredstvima financira različite zelene projekte, bilo direktno bilo promoviranjem važnosti korištenja obnovljivih izvora i štednje energije. Grad je također omogućio zapošljavanje lokalnog stanovništva, odnosno osigurao da kapaciteti i resursi upravljanja i opskrbe energijom ostanu u lokalnoj nadležnosti (Robin Hood Energy, 2018).

Mala hidroelektrana u Pleternici prva je elektrana u vlasništvu jedinice lokalne samouprave te je primjer ulaganja grada $\mathrm{u}$ energetsku tranziciju u Hrvatskoj. Kako bi grad zadovoljio svoje energetske potrebe izgradio je hidroelektranu snage $220 \mathrm{~kW}$ s godišnjom proizvodnjom od 1,1 milijun kW električne energije vrijednosti 850.00-900.000 HRK. Cijena investicije bila je 4,8 milijuna kuna prilikom čega je grad osigurao 50\% iznosa, Fond za zaštitu okoliša i energetsku učinkovitost 1,7 milijuna kuna te Ministarstvo regionalnog razvoja 0,5 milijuna kuna. Električna energija proizvedena u elektrani trebala bi biti dovoljna za troškove javne rasvjete grada i 35 okolnih naselja prilikom čega bi se ušteda energije koristila u druge svrhe kao što su kulturni, socijalni i drugi projekti koji su izvan dohvata zbog malog proračuna (Hrastović Inženjering, 2012).

\section{Zadružni model u energetskom sektoru}

Energetske zadruge važni su pokretači ekonomskih, gospodarskih, društvenih i energetskih promjena na lokalnoj, regionalnoj; čak i na državnoj razini. U Njemačkoj je instalirano 50\% kapaciteta OIE kroz energetske zadruge, a u Danskoj 70\% vjetroelektrana je u vlasništvu građana. Europska Unija u Energetskom paketu potiče aktivnu ulogu građana u energetskoj tranziciji. Aktivna pozicija građana omogućava sudjelovanje u odlučivanju, vlasništvu te dobiti od energetskog sektora (Silva \& Šahović, 2016). Jedan vid aktivnog sudjelovanja je udruživanje $u$ energetske zadruge koje se sastoje od pojedinaca, tvrtki, lokalnih samouprava, javnih ustanova te je njihov cilj razvoj energetskih projekata. Udruživanje omogućuje disperziju rizika investicije, veću pregovaračku moć, djelovanje kao organizacija te dijeljenje znanja i dobiti unutar zajednice (Nacionalno koordinacijsko tijelo za energetsku učinkovitost, 2018). Zadružna poduzeća razlikuju se od ostalih poduzeća prema ciljevima između članova (međusobna korist, odnos proizvodnje-usluge-potrošnje unutar zajednice), vođenju (demokratska kontrola, zadružna autonomija, sudjelovanje članova) te po financijskoj strukturi (uloga kapitala, alokacija profita te zadružno financiranje) (Silva \& Šahović, 2016). 
Građani ostvaruju članstvo u energetskoj zadruzi kupnjom udjela te time postaju članovi ili suvlasnici lokalnih energetskih projekata. Članovi međusobno dijele dobit, mogu kupovati električnu energiju po realnim cijenama, sudjelovati u odlučivanju o investicijama i cijenama energije. Energetske zadruge uklanjaju NIMBY efekt protiv postavljanja OIE omogućavanjem pristupa građanima kroz investiranje i upravljanje elektranama. Fokus energetskih zadruga je na građanima i zajedništvu, pa tako je visina potencijalnih investicija dostupna svim građanima, a viškovi investicija se najčešće koriste za dijeljenje dobiti i za pokretanje novih projekata čime se potiče lokalna ekonomija i zaposlenje (REScoop,2018). Energetske zadruge proizvode energiju iz raznih izvora; primarno iz vjetra, sunca, vode ili biomase. Lokalni karakter energetskih zadruga pridonose decentralizaciji proizvodnje energije, a same zadruge ponekad mogu preuzeti ulogu energetskih tvrtki kod trgovanja energijom, kupnjom mreže i slično. Fokus zadruga je ponajviše na javnom interesu i zajedničkom financiranju putem svojih članova (Ogunleye, 2018).

Vrijednosti energetskih zadruga (REScoop,2018):

- volontersko i otvoreno članstvo;

- demokratska kontrola;

- ekonomsko sudjelovanje kroz izravno vlasništvo;

- autonomija i neovisnost;

- edukacija, trening i informiranje;

- suradnja među članovima;

- briga za zajednicu.

Energetske zadruge mogu se smatrati oblikom startup poduzeća koje varira u profesionalizmu i zrelosti. Energetske zadruge imaju mogućnost preuzeti uloge energetskih tvrtki kao što su: proizvodnja energije, dobavljanje energije, trgovanje energijom te pružanje usluga krajnjem korisniku. Zadruge obično započinju s volonterima; aktivnim članovima društva koji dijele svoje vrijeme, znanje i vještine kako bi stvorili poduzeće koje bi bilo održivo. Takvi članovi imaju iskustva u energetskom sektoru, tehnologijama, komunikaciji, volonterskom menadžmentu, zakonskim i administrativnim procesima. Kako bi zadruge opstale moraju stvarati profit kako bi održale članove s kompetencijama i iskustvom u energetskom području. Nakon volonterskog oblika zadruge nastupa osnivanje tvrtke ili organizacije pri čemu članovi donose odluke kao što su: izbor tehnologija (tehnički i operativni problemi), okupljanje novih članova i volontera, komunikacija i marketing, financiranje, zakonske i regulativne prepreke te buduće planiranje. U interesu svakog startup-a je stvaranje pozitivnog toka novaca kako bi mogli održati svoje aktivnosti npr. izdavanje popusta svojim kupcima, 
okupljanje novih članova, održavanje električnog vozila, poštovanje ugovora o najmu, podizanje svijesti i savjetovanje o uštedi energije, razvoj projekata zelene energije. Kako bi se aktivnosti ostvarile potrebno je privući investicije i subvencije (R\&Dialogue, 2018).

Velik broj pojedinaca želi investirati u OIE ili instalirati tehnologije OIE na svojem posjedu. Projekti zelene energije mogu biti kapitalno intenzivni, traže znanje na području ekonomije, prava, administracije i tehnička znanja koje pojedinac često ne može imati. Prednost zadruga jest u tome da mogu riješiti većinu tih pitanja te smanjiti administrativne troškove i podijeliti odgovornost između članova. Primjerice članovi zadruge mogu investirati u OIE te podržati njihovo korištenje kroz skromne investicije. Velikim brojem članova koncentrira se dostupan kapital, ali i znanje na području ekonomije i zakonskih propisa čime se postiže veća efikasnost pri provedbi energetskih projekata (Boenigk et al., 2012).

Jedan od primjera je prva fotonaposka elektrana FWR-a snage $270 \mathrm{~kW}$ instalirana na krovu Bad Neustadt komunalne tvrtke 2008. Elektrana proizvodi 235.000 kWh godišnje što je jednako energetskim potrebama 60 kućanstava. Životnim vijekom od 20 godina sustav će uštedjeti 4.150 tona $\mathrm{CO}_{2}$. Investitori koji su uložili 4.000 EUR doprinose proizvodnji zelene električne energije potrebne za opskrbu njihovog kućanstva. Cjelokupna investicija u elektranu je 1,1 milijun EUR od čega je 2/3 investicije financirano kroz posuđivanje, a $1 / 3$ je financirana udjelima $u$ elektrani. Svakom građaninu Bad Neustad bio je ponuđen udio u elektrani cijene 2.000 EUR od čega 100 EUR ide u energetsku zadrugu kao udio, dok se ostatak investira kao pozajmica na 20 godina za financiranje projekta. Efektivna kamatna stopa projekta procjenjuje se na 5,5\% godišnje (Boenigk et al., 2012).

Energetska zadruga "Otok Krk" nastala je u srpnju 2012. od strane 19 osnivača s namjerom da otok postane energetski neovisan pomoću različitih obnovljivih izvora energije. Vizija zadruge je ostvariti i druge ekološke ciljeve kao što su: poticanje elektromobilnosti, energetske efikasnosti, racionalnog korištenja resursa (prvenstveno vode) te potaknuti bolje gospodarenje otpadom. Zadruga želi ostvariti svoje ciljeve uključivanjem građana u proces energetske tranzicije i neovisnosti otoka. Osim građana članovi zadruge su ekološki osviješteni pojedinci, otočne lokalne samouprave, predstavnici udruga i komunalno društva Ponikve d.o.o, koje energetskoj zadruzi pruža veliku logističku podršku.

Zadruga je pokrenula edukaciju građana o važnosti i mogućnosti proizvodnje energije iz OIE za svoje potrebe te im pomaže pri nabavi i instalaciji OIE po smanjenim cijenama. Tvrtka Ponikve d.o.o. izradila je strategiju nulte emisije za otok Krk, katastar krovova, studiju izvodljivosti za izgradnju energane/toplane na biomasu te izgradila fotonaponsku elektranu snage $133 \mathrm{~kW}$ na zgradi deponija. Zadruga nudi građanima pomoć pri izgradnji sustava zagrijavanja vode i 
instalaciju fotonaposkih panela kroz informativne letke o radu zadruge i važnim pitanjima koja opisuju stanje krovova građana tj. pogodnost krovova za ugradnju toplinskih ili električnih sustava. Kupnjom sustava putem zadruge građani ostvaruju pogodnosti kao što su: jeftinija ili besplatna dokumentacija za status povlaštenog proizvođača, jeftinija oprema (zbog masovne nabave opreme) i povišenje najma krovova s 4\% na 15-16\% (Brničević et al., 2013).

\section{Primjena i perspektiva blockchain tehnologije $\mathbf{u}$ energetskom sektoru}

Blockchain tehnologija je nova tehnologija koja može doprinijeti optimizaciji proizvodnje, skladištenja, razmjene i potrošnje električne energije za sve građane. Njene karakteristike su internetska sigurnost, niski troškovi transakcije, automatizacija procesa i pametni ugovori (eng. smart contracts). Blockchain ima razvijen mehanizam koji onemogućuje promjenu nad podacima koji su jednom upisani u blockchain ili u najmanju ruku omogućuje lako otkrivanje promjena na podacima.

Blockchain služi za suradnju između različitih članova zajednice (proizvođači i potrošači energije) kroz transparentnost i građenje povjerenja. Decentralizirane baze podataka mogu dijeliti podatke, osvježiti podatke i distribuirati potrebne podatke te u kombinaciji s pametnim brojilima mogu poboljšati efikasnost, otpornost i transparentnost postojećih energetskih mreža. Fleksibilnije i efikasnije mreže mogu privući kapitalna ulaganja u mrežu smanjenjem ekonomskih gubitaka i otpada prilikom čega bi velike tvrtke mogle biti predvodnici u pronalaženju najefikasnijih usluga pri integraciji prosumera u postojeću mrežu te natjecati se s građanima u pružanju usluga korisnicima (Kessler \&UNDP ALTFINLAB, 2018).

Tehnologija blockchaina je zapravo baza podataka koja se replicira preko peer-to-peer (P2P) mreže (Hileman \& Rauchs, 2017). Proces pohranjivanja podataka u bazu podataka može se odvijati kroz dvije faze. Prva faza uključuje parcelaciju informacija u blokove, zatvaranje bloka i dodavanje prethodnom bloku. U drugoj fazi svaki lanac blokova pohranjuje se distribuirano kroz cijelu mrežu (Kessler \&UNDP ALTFINLAB, 2018). Blockchain se razlikuje od ostalih baza podataka po dosljednosti i pouzdanosti zapisa tj. prema pravilima ugovora između sudionika $u$ blockchain mreži. Prednost mreže je $u$ tome što nema potrebe za stvaranjem „povjerenja“ između dionika nego se svi podaci izmjenjuju mehanizmima dogovora, a svi zapisi u bazi podataka vidljivi su svim sudionicima. Vrijednost blockchain tehnologije leži u sposobnosti da samostalno provjeri integritet zajedničke baze podataka bez uključivanja treće strane. Provjeravanje integriteta od više strana onemogućuje zlonamjerno mijenjanje baze podataka. Kako bi to bilo moguće potrebne su tehnologije kao što su kriptografija, P2P mreža, 
mehanizam konsenzusa, registrator transakcija i pravila o valjanosti (Hileman \& Rauchs, 2017).

Tablica 2. Koristi blockchain tehnologije (Kessler \&UNDP ALTFINLAB, 2018)

\begin{tabular}{|c|c|}
\hline $\begin{array}{l}\text { Nepromjenjivost } \\
\text { podataka }\end{array}$ & $\begin{array}{l}\text { Blockchain stvara više kopija kroz P2P mrežu kroz konsenzus } \\
\text { između korisnika što onemogućuje izmjenu prošlih transakcija }\end{array}$ \\
\hline Sigurnost & Kriptografija onemogućuje izmjene \\
\hline Dokazivanje & Transakcije su slijeve i lako ih je dokazati kroz cijeli mrežu \\
\hline Otpornost & $\begin{array}{l}\text { Ako se dio mreže ugasi, podaci su još uvijek dostupni u drugom } \\
\text { djelu mreže }\end{array}$ \\
\hline Transparentnost & $\begin{array}{l}\text { Transakcije se šalju u mrežu, a ne na jedno mjesto s time da je } \\
\text { privatnost korisnika osigurana kroz enkripciju podataka }\end{array}$ \\
\hline
\end{tabular}

Blockchain bi mogao biti dio paralelnih mreža unutar postojećih koje bi potaknule investiranje u OIE i ubrzale decentralizaciju energije. Proizvedena energija izmjenjuje se administrativno preko jednog dobavljača te time nisu ostvareni uvjeti za paralelnu mrežu unutar postojećeg sustava. Trgovanjem unutar paralelne mreže (manjeg tržišta) može se ostvariti dodatna vrijednost proizvedene energije tj. stvoriti mogućnost negativnog oporezivanja kod kojeg bi svaki MWh proizveden iz OIE stvarao dodatnu vrijednost iz poreza na energiju proizvedenu iz fosilna goriva (Kessler \&UNDP ALTFINLAB, 2018).

Blockchain tehnologija značajno pojednostavljuje sljedeće procese:

- Decentralizirana kupovina/prodaja električne energije;

- Upravljanje potrošnjom i uslugama u sustavu (omogućene od strane naprednih sudionika);

- Implementacija pametnih ugovora u punjenju/pražnjenju električnih vozila;

- Jamstva o podrijetlu, certificiranje OIE proizvodnje;

- Jamstva o podrijetlu, certificiranje emisijskih kvota i

- Automatizirano mjerenje i obračun potrošnje električne energije. 

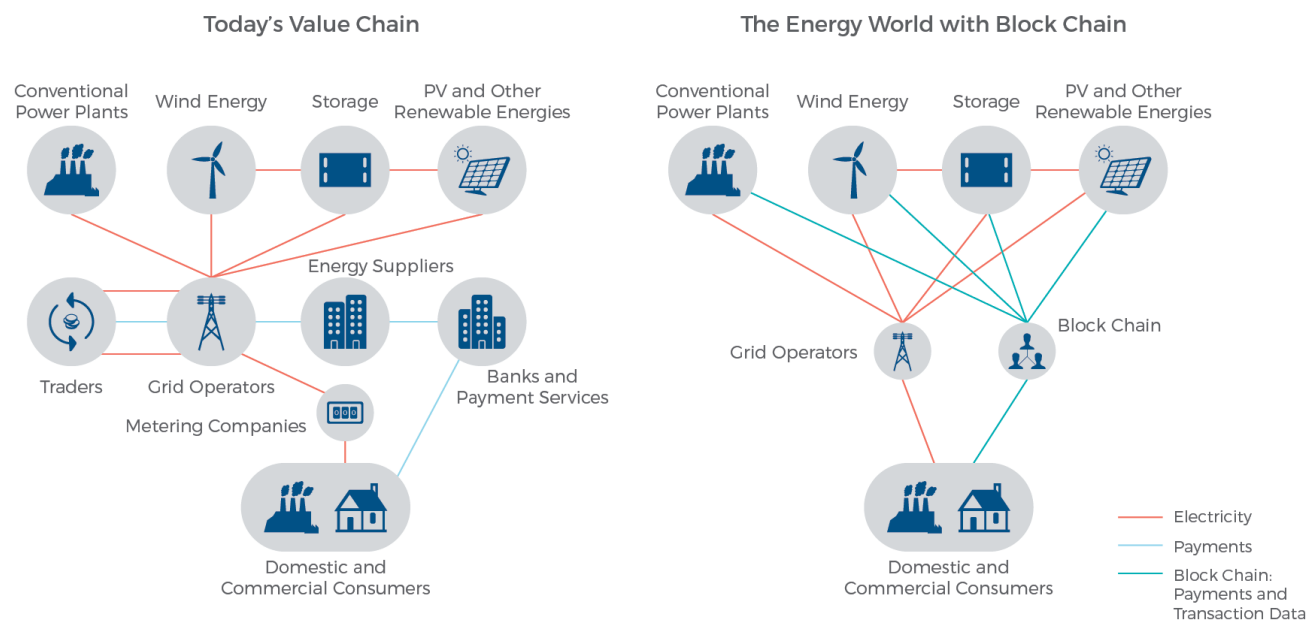

Slika 3. Bockchain tehnologija preuzima ulogu energetskih tvrtki i financijskih institucija u energetskom sektoru (Kessler \&UNDP ALTFINLAB, 2018)

Tehnološka otkrića kao što su pametna brojila i tehnologije OIE zahtijevaju novi pristup razmjene energije između korisnika kroz mikro mreže i manja tržišta energije. Blockchain tehnologija omogućuje efikasnije trgovanje i razmjenu energije te pokazuje potencijal za smanjenje troškova kroz smanjenje utjecaja monopola energetskih tvrtki kod trgovanja energijom. Pametni ugovori mogu dodatno decentralizirati postojeću mrežu kroz poticanje čiste energije i smanjenja potrošnje energije (Kessler \&UNDP ALTFINLAB, 2018).

SunContract je slovenski start-up projekt koji omogućava trgovinu električnom energijom bez posrednika. Radi se o platformi koja izravno povezuje proizvođače energije iz obnovljivih izvora i potrošače te im omogućava trgovinu energijom. Projekt se odvija pomoću Ethereum tehnologije i izdaje vlastite tokene pod nazivom SNC. SunContract-ova vizija je podržati globalnu samodostatnu energetsku komunikaciju na temelju obnovljive energije i izravne (peer-to-peer) energije. Temelji se na trgovanju preko blockchaina i pametnih ugovora. Stvaranjem takvog ekosustava, Suncontract želi pridonijeti većoj neovisnosti kada je u pitanju električna energija te eliminirati potrebu za neovisnom trećom stranom. Digitalizacijom trgovanja električnom energijom na blockchainu trgovanje postaje fleksibilnije, transparentnije i lakše sljedivo (SunContract, 2018.). 


\section{ZAKLJUČAK}

Usporedno s razvojem novih inovativnih tehnoloških rješenja u području elektroenergetskog sektora, primjerice električni automobili, sustavi za skladištenje električne energije, blockchain tehnologija i dr., razvijaju se i inovativni poslovni i društveni modeli, kako u Europi tako i diljem svijeta. Ono što je zajedničko svim inovativnim kretanjima jest podjednaka zainteresiranost velikih elektroenergetskih kompanija kao i pojedinih građana ili lokalnih zajednica kao primjera manjih investitora. Pojedine energetske tvrtke prepoznale su potencijal energetske tranzicije i zelenog razvoja te inovativnim poslovanjem postaju važni aktori u energetskom sektoru. Lokalne jedinice samouprave rade na energetskoj neovisnosti gradnjom vlastitih postrojenja za proizvodnju energije i poticanjem energetske efikasnosti čime ostvaruju povezanost s građanima te postaju predvodnici niskougljičnog razvoja. Donošenje potrošačkih odluka pri odabiru opskrbljivača i političkih izbora od strane građana nisu jedini mehanizmi kojim se uključuju u energetsku tranziciju već aktivno zauzimajući ulogu investitora $u$ energetska postrojenja, proizvođača energije, vlasnika postrojenja te osnivanjem energetskih zadruga postaju punopravni dionici u promjenama u energetskom sektoru. Osnaživanjem svih dionika mogu se ostvariti zadani ciljevi po pitanju zaštite okoliša i proizvodnje čiste energije. Većina opisanih modela je primjenjivo na energetski sektor već sada, a neki se koriste već godinama. Model koji je dalje od komercijalne isplativosti, ali ima velik potencijal je primjena blockchain tehnologije u energetici kojom se želi ostvariti smanjenje troškova, transparentnost i povezivanje navedenih sudionika u zelenom razvoju.

\section{LITERATURA}

1. A. BERGMANN, B. BURTON, M. KLAES, S. BETZ and T. MAIDONIS, (2016), Crowdfunding for Renewable Energy: Survey Results on Public Perceptions and the Views of Crowdfunding Platforms and Project Developers Preuzeto 06.04.2018. iz Research Gate web stranice: https://www.researchgate.net/publication/305687343_Crowdfunding_for_Renewable_Energy_Survey_Results_on_ Public_Perceptions_and_the_Views_of_Crowdfunding_Platforms_and_Project_Developers (str. 11).

2. Bettervest. (2018). Sustainable investments. Preuzeto 17.05.2018. iz Bettervest web stranice: https://www.bettervest.com/en/about

3. N. BOENIGK, B. DANNEMANN, C. THIEM, J. VEßHOFF, A. WIEG (2012). Energy Cooperatives Citizens, communities and local economy in good company. Preuzeto 19.09.208. iz CleanEnergyAction web stranice: ttps://cleanenergyaction.files.wordpress.com/2012/10/energycooperatives 
4. F. BRNIČEVIĆ, M. ĐUKAN, E. JERKIĆ, M. KIRAC, A. LUCIĆ, T. MEDIĆ, D. MILETIĆ, R. PAŠIČKO, I. SZEKERES, M. VAJDIĆ, (2013). Priručnik za osnivanje energetskih zadruga u Hrvatskoj. Preuzeto 25.06.2018. iz Hrvatska znanstvena bibliografija: https://bib.irb.hr/datoteka/828110.energetske_zadruge_2.pdf

5. Convenant of mayors. (2018). About the Covenant of Mayors. Preuzeto 24.02.2018. iz Convenant of mayors web stranice: http://www.covenantofmayors.eu/

6. Citizenergy. (2018). How it works. Preuzeto 08.04.2018. iz Citizenenergy web stranice: https://www.citizenergy.eu/

7. Environmental Defense Fund. (2018). How climate change plunders the planet. Preuzeto: 01.06.2018. iz Environmental Defense Fund web stranice: https:// www.edf.org/climate/how-climate-change-plunders-planet

8. EPA. (13.03.2018). Centralized Generation of Electricity and its Impacts on the Environment. Preuzeto 20.05.2018. iz EPA web stranice: https://www.epa.gov/ energy/centralized-generation-electricity-and-its-impacts-environment

9. European Commission. (07.06.2018.). International agreements on climate action. Preuzeto 29.05.2018. iz European Commission: http://www.consilium.europa.eu/en/policies/climate-change/international-agreements-climate-action/

10. Eurostat. (2017). Oil and petroleum products - a statistical overview. Preuzeto 15.05.2018. iz Eurostat web stranice: https://ec.europa.eu/eurostat/statistics explained/index.php/Oil_and_petroleum_products_-_a_statistical_overview

11. Gen-Isonce. (2018). Zakaj GEN-I Sonce?. Preuzeto 20.01.2018. iz Gen-isonce web stranice:https://www.gen-isonce.si/

12. Greenpeace. (2014). LOCKED IN THE PAST WHY EUROPE'S BIG ENERGY COMPANIES FEAR CHANGE. Preuzeto 01.06.2018. iz Greenpeace web stranice: https://www.greenpeace.org/archive-eu-unit/Global/eu-unit/reports-briefings/2011\%20pubs/2014\%20Jan-April/20140227\%20RP\%20LOCKED\%20 IN\%20THE\%20PAST\%20-\%20Why\%20Europe's\%20big\%20energy\%20companies\%20fear\%20change.pdf

13. H. HAFNER, Udruga SMART. (2017). VODIČ ZA CROWDFUNDING. Rijeka: Udruga za razvoj civilnog društva SMART, pp.1-7. Preuzeto 04.04.2018. iz Crowdfunding web stranice: http://www.crowdfunding.hr/vodic-za-crowdfunding-3728

14. G.HILEMAN, M. RAUCHS (2017). 2017 Global Blockchain Benchmarking Study. Preuzeto 18.09. iz web stranice: https://papers.ssrn.com/sol3/papers. cfm?abstract_id=3040224

15. Hrastović Inženjering. (2012). Mala hidroelektrana Pleternica. Preuzeto 18.09.2018. iz Hrastović Inženjering web stranice: https://www.hrastovic-inzenjering.hr/ primjena-energije/energetski-clanci/energijske-tehnologije/item/523-mala-hidroelektrana-pleternica.html 
16. IEA. (2014). World Energy Investment Outlook. Preuzeto 18.09.2018. iz International Energy Agency web stranice: http://www.iea.org/publications/freepublications/publication/name,86205,en.html 287

17. Infrachain. (2018). Why infrachain?. Preuzeto 16.02.2018. iz Infrachain web stranice: https://infrachain.com/

18. Intergovernmental Panel on Climate Change (IPPC). (2007). Fourth Assessment Report (AR4): The Physical Science Basis of Climate Change. Preuzeto 27.05.2018. iz IPPC web stranice: https://www.ipcc.ch/publications_and_data/publications_ipcc_fourth_assessment_report_wg1_report_the_physical_science_basis.htm

19. S. Kessler (2018). UNDP ALTFINALAN. The future is decentralised block chains, distrubuted ledgers \&the future or sustainable development. Preuzeto 18.09.2018. iz UNDP web stranice: http://www.undp.org/content/dam/ undp/library/innovation/The-Future-is-Decentralised.pdf

20. Ministarstvo zaštite okoliša i energetike. (2017). „Nacrt strategije niskougljičnog razvoja Republike Hrvatske do 2030. godine s pogledom na 2050. godinu“" Zagreb: Ministarstvo zaštite okoliša i energetike.

21. Ministarstvo zaštite okoliša, prostornog uređenja i graditeljstva. (2011). Strateške odrednice za razvoj zelenog gospodarstva. Hrvatska, Zagreb Preuzeto 10.05.2018. iz Vlada Republike Hrvatske web stranice: https://vlada.gov.hr/ UserDocsImages/Sjednice/Arhiva/117153.\%20-\%201.3.pdf (str.4).

22. Nacionalno koordinacijsko tijelo za energetsku učinkovitost. (2018). Energetske zadruge. Preuzeto 09.06.2018. iz: Nacionalni portal energetske učinkovitosti: https://www.enu.hr/ee-u-hrvatskoj/tko-je-tko-ee-rh/energetske-zadruge/

23. O. OGUNLEYE (2018). Power to the People: Assessing Renewable Energy Coops in Ontario. Preuzeto 04.06. 2018. iz University of Ottawa iz: https://ruor. uottawa.ca/bitstream/10393/37985/1/Ogunleye_Olaoluwa_2018_thesis.pdf

24. R. PAŠIČKO (2014). OPTIMIZATION OF POWER SYSTEM OPERATION AND DEVELOPMENT UNDER EMISSION TRADING SCHEME. Preuzeto 18.09.2018. iz Hrvatska znanstvena bibliografija: https://bib.irb.hr/datoteka/828112.PhD_Thesis_Robert_Pasicko.compressed.pdf (str. 34,48-51).

25. PwC global power and utilities. (2017). Blockchain - an opportunity for energy producers and consumers?. Preuzeto 10.02.2018. iz PwC web stranice: https:// www.pwc.com/gx/en/industries/assets/pwc-blockchain-opportunity-forenergy-producers-and-consumers.pdf (str. 15-24).

26. Republika Slovenija. (2015). „Uredba o samooskrbi z električno energijo iz obnovljivih virov energije", Uradni list Republike Slovenije, Volume 97, p. 12080., 2015.f. 
27. Reneweble Energy Policy Network for the 21st Century. (2017). Highlights of the REN21 Renewables 2017 Global Status Report in perspective. Preuzeto 12.05.2018. iz Reneweble Energy Policy Network for the 21st Century web stranice: http://www.ren21.net/wp-content/uploads/2017/06/GSR2017_Highlights_FINAL.pdf

28. REScoop. (2018). What is REScoop?. Preuzeto 19.09.2018. iz REScoop web stranice: https://www.rescoop.eu/the-rescoop-model

29. Robin Hood Energy. (2018). How much could you save? Preuzeto 15.03.2018. iz RobinHoodenergy web stranice: https://robinhoodenergy.co.uk/

30. R\&Dialogue. (2018). Local energy cooperative-case study. Preuzeto 05.06.2018 iz Triari web stranice: http://www.triarii.nl/docs/RnDialogue $\% 20$ case $\% 20$ study\%20-\%20local\%20energy\%20cooperatives.pdf

31. P. SILVA, N. ŠAHOVIĆ (2016). Community Renewable Energy - Research Perspectives. Preuzeto 02.06.2018. iz ScienceDirect web stranice: https://www.sciencedirect.com/science/article/pii/S1876610216316629

32. Smartcity Wien. (2018). SOLAR ENERGY FOR EVERYONE. Preuzeto 22.02.2018. iz Smartcity Wien web stranice: https://smartcity.wien.gv.at/site/ en/citizens-solar-power-plants/

33. Smartgrid. (2018). What is Smart Grid?. Preuzeto 02.07.2018. iz Smartgrid web stranice: https://www.smartgrid.gov/the_smart_grid/smart_grid.html

34. SunContract. (2018). Decentralized Energy Market. Preuzeto: 16.02.2018. iz SunContract web stranice: https://suncontract.org/

35. Tverberg G. (19.09.2013). Oil Prices Unlikely to Climb Much Higher. Preuzeto 14.05.2018. iz Oilprice web stranice: https://oilprice.com/Energy/Oil-Prices/ Oil-Prices-Unlikely-to-Climb-Much-Higher.html

36. Wien Energie. (2018). Citizen solar power plants. Preuzeto 21.01. 2018. iz Wien Energie web stranice: https://www.wienenergie.at/eportal3/ep/channelView. do/pageTypeId/67860/channelId/-51749

37. Worldbank. (2012). Inclusive Green Growth The Pathway to Sustainable Development. Preuzeto: 04.05.2018. Worldbank web stranice: http://siteresources.worldbank.org/EXTSDNET/Resources/Inclusive_Green_Growth_ May_2012.pdf (str.2).

38. World Economic Forum. (2018).Transformation of the Global Energy System. Preuzeto 02.07.2018. iz World Economic Forum web stranice: http://www. weforum.org/docs/White_Paper_Transformation_Global_Energy_System_ report_2018.pdf (str. 4-6).

39. Zelena energtetska zadruga. (2018). Križevački sunčani krovovi. Preuzeto 16.05.2018. iz Zelena energetska zadruga web stranice: http://www.zez.coop/ ulaganja/ 


\section{SAŽETAK \\ NOVI KONCEPTI ZELENOG RAZVOJA I NJIHOVA PRIMJENA U ENERGETICI}

Niz promjena na svjetskoj razini utječe na energetski sektor; posebice elektroenergetski. Ciljevi modernih država mijenjaju se zbog želje građana za boljom kvalitetom okoliša, postizanjem energetske sigurnosti i poštenije cijene energije uz sprečavanje posljedica klimatskih promjena i umanjivanje njihovih efekata. Globalni pomak za postizanje tih ciljeva očituje se povećanjem investicijskih napora, prihvaćanjem klimatskih sporazuma kroz nacionalne politike te razvojem različitih tehnologija (solarni sustavi, vjetroelektrane, električna vozila, sustavi baterija, pametne mreža, blockchain itd.),. Iako pojedini akteri još uvijek nisu prepoznali potencijal zelenog razvoja sve veći broj građana, organizacija i energetskih tvrtki uključuje se aktivno kroz energetsku tranziciju.

Inovacije koje nosi zeleni razvoj posebice su zanimljive jer privlače aktere s različitom poslovnom pozadinom. Kako bi energetska tranzicija dobila dovoljan zamah sve više organizacija je uključeno u inovativno dizanje kapitala za projekte zelene energije kao što su platforme za grupno financiranje. Osim toga vidljiv je pomak pri oslobađanju kapitala manjih energetskih tvrtki koje iznajmljuju opremu za energetska postrojenja od strane građana ili koriste druge inovativne poslovne modele kako bi povećale udio obnovljivih izvora energije $u$ energetskom portfelju te uključile građane $u$ poslovanje. Lokalne vlasti sve više prepoznaju i prihvaćaju volju građana za poštenijim energetskim sustavom pri čemu preuzimaju aktivnu ulogu u borbi protiv klimatskih promjena i u energetskoj tranziciji. Razvoj novih koncepata zelenog razvoja omogućuje razvijanje povjerenja između energetskih tvrtki i krajnjih korisnika.

Ključne riječi: obnovljivi izvori energije; energetske zadruge; grupno financiranje; blockchain; energetska tranzicija; zeleni razvoj. 


\section{SUMMARY}

\section{NEW CONCEPTS FOR GREEN DEVELOPMENT AND THEIR APPLICATION IN ENERGY SECTOR}

A number of world-wide changes affect the energy sector; especially electric sector. The goals of modern states are changing due to the increasing desire of citizens to improve the quality of the environment, disere to achieve energy security and will to get a more honest price of energy, as well as preventing the consequences of climate change and mitigate their effects. Global progress towards achieving these goals is reflected in: increased investment efforts, the adoption of climate agreements through national policies and the development of various technologies (solar systems, wind power plants, electric vehicles, battery systems, smart grids, blockchain etc.). Although some actors have not yet recognized the potential of green development, an increasing number of citizens, organizations and energy companies are actively involved and linked through the energy transition.

Green development is full of invoative process and it includes actors with different business background. In order for the energy transition to gain momentum, more and more organizations are involved in the alternative funding of green energy projects such as crowdfunding platforms. In addition, there is a visible shift in the capital raising of smaller energy companies that rent equipment from citizens for power plants or use other innovative business models to increase the share of renewable energy sources in their energy portfolio and involve citizens in process. Local authorities increasingly recognize and accept the need for more honest energy system by taking on an active role in combating climate change and energy transition. The development of new concepts of green development enables building of trust between energy companies and end users.

Key Words: renewable energy sources; energy cooperatives; crowdfunding; Blockchain; energy transition; green development. 